\title{
The Influence of Life Purpose to Instrinsic Motivation and Job Achievement among the Employees of Paper Mill Factory in East Java Province, Indonesia
}

\author{
Maya Ida Kesumawatie \\ Lecturer at School of Economics (STIE) Mahardhika, Surabaya, Indonesia \\ Corresponding Author: Maya Ida Kesumawatie
}

\begin{abstract}
This study is to describe the relationship between life purpose and instrinsic motivation and the impact to the job achievement among the employees in paper mill factory in East Java province, Indonesia. The data was collected from 165 operator level employees in production department, consists of Deinking Plant, Stock Preparation and Paper Mill. There are three findings of the study, firstly, the life purpose significantly influences the instrinsic motivation and shown by the $p$ value of 0,003. Secondly, the life purpose influences significantly the job achievement that shown by $p$ value of 0,054 and thirdly, the instrinsic motivation influences the job achievement significantly, shown by $p$ value of 0,025 .
\end{abstract}

Keywords: life purpose, instrinsic motivation, job achievement

Date of Submission: 26-06-2017

Date of acceptance: 15-07-2017

\section{Introduction}

The business world shows a very rapid development which is followed by the emergence of new company companies that engaged in various fields. In doing the business, a company always tries to get a favorable position or condition. The such condition will lead to a very tight competition among existing companies.

Competition is also getting stronger due to the development and increasingly sophisticated of information technology especially and resulting in the existence of competition globally and thoroughly. The existence of human resources within a company plays a very important role. Humans have great potential to run the company's activities. The potential of every human resources in the company should be utilized as well as possible, so it will provide maximum results. Company and employees are two things that are interrelated. If the employees can bring progress to the company, both parties will earn the profit. For employees, the success is a part of self potential actualization and opportunity to fulfill their life needs, while for company, success means the growth and development of the company. Human resources is the sole asset of a company that has the intellectual, feelings, desires, knowledges, drivers, power and work of a person who will be the most valuable investment in an organization that becomes a valuable main asset and must be recognized for its existence as a key even acts as decisive factor in carrying out the vision, mission and goals of the organization. That is why the role of human is immense as a driving force and agent of change. Therefore, to achieve the work performance expected by the company, it takes motivation of the person, where the motivation is related to the life purpose which becomes motivators in the person's self.

Life purpose and motivation of a person will not only support the achievement of a person's goal but also the goal of the company. Motivating is starting point of a chain from the needs, desire, action and decision. All the stages of motivation, the main factors which are the purposes and direction of behavior of one's life and the provision of motivation must be directed to the achievement of organizational goals.

The purpose of this study is to examine the relationship between the life purpose and intrinsic motivation and its impact on job achievement.

\subsection{Life Purpose}

\section{Theoretical Thinking And Development Of Hypothesis}

The life purpose is something that is considered important and valuable, and provides a special value for someone. If the meaning of the life purpose is found and fulfilled then it will make the life meaningful and valuable (Bastaman, 2007) Understanding what life is about is what to be accomplished and fulfilled in life. The meaning of this life purpose really exists in life itself, although in reality it is not easy to find, because it is often implied and hidden. If the meaning of this life purpose is found and fulfilled the life is meaningful and lead to 
happiness. Then it can be said that happiness is a reward or a side effect of one's success in fulfilling the meaning of life purpose.

According to Frankl (1970) the meaning of life's purpose must be seen as an objective matter because it relates the individual's relationship with his experience in this world, although the meaning of the life purpose itself is actually objective because it is real and experienced in life.

Everyone who's doing an activity in his life, must have a certain motivation and purpose. How one can expect the destination if one does not know where to go "(Bremer, 1995). "The secret of success lies in the determination of purpose" (Benyamin Disraeli) and not everyone knows the goals to be achieved in life. H1 : Life purpose has a positive and significant influence to the instrinsic motivation $\mathrm{H} 2$ : Life purpose has a positive and significant influence to the job achievement

\subsection{Instrinsic Motivation}

Motivation is the factor that exists in a person who can move or direct his behavior to meet certain goals (Indriyo and Sudita, 2008). People who have the high ability, skills and knowledge do not automatically generate high job achievement. The achievement shown by a person in the organization is determined not only by his or her skills, knowledge, and abilities but also by other factors such as motivation, intention from within a person to use all his/her abilities.

According to Syaiful Bahri (2002: 115) intrinsic motivation is the motives that become active or functioning without requiring external stimulation because it lies in each individual as a driver to do something. $\mathrm{H} 3$ : intrinsic motivation has a positive and significant influence to the job achievement

\subsection{Job Achievement}

According to Nindyati (2003: 22) in understanding the job achievement can not be separated from the multidimensional understanding. The willingness and ability of a person in doing the job can be seen from his Job Achievement, in an effort to apply the concepts, ideas in effective and efficient ways so the goals set can be achieved by the company. But this ability is not only in the ability to manage, but lead and apply all the abilities that exist in him to achieve the goals set together in a company unit.

Thus, job achievement means achievement or contribution given by employees in carrying out duties, responsibilities and functions as employees in the company. In addition, job achievement is limited as a result of employee work behavior that supports the achievement of output or achievement and is related to the effort to complete the task in a certain period of time. The results reflected in the behavior are influenced by motivation (Mangkunegara, 2005:91)

\subsection{Procedures and Sampling}

\section{Research Method}

The type of research used in this research is explanatory with quantitative approach. The explanatory research according to Sugiyono (2006) is a study that explains the causal relationship between the variables that affect the hypothesis. The target population in this study is from several Paper Mill in East Java, which is individual investment and the production capacity of its production is $350-500$ ton / day. This is to help researchers get a good criteria on the quality of job achievement of employees. Hair et al. In Ferdinand, (2002: 48) suggests that the sample size depends on the number of indicators used in all latent variables. It is recommended that the minimum sample size be 5-10 observations for each parameter estimate. Based on the above opinion, the minimum sample size in this study is: $n=8 \times$ number of indicators, where $n$ is the minimum sample number. Indicator used in this research as many as 12 indicators, so that obtained minimum sample are 96 respondents.

\subsection{Samples Characteristics}

Respondents as the source of information to obtain primary data were taken from the operator level employees in the production department, in Deinking Plant, Stock Preparation and Paper Machine. The samples were calculated using simple random sampling by the Slovin formula. Samples of 165 respondents were obtained.

\subsubsection{Measurement Instruments}

To answer the problem and to test the proposed hypothesis, then the data obtained will be processed in accordance with the needs of the analysis. For discussing, the data is processed and presented based on the principles of descriptive statistics, while for the purposes of hypothesis analysis and testing used inferential statistical approach. In order to answer the research question and evaluate the model, the analytical technique used is Structural Equation Modeling (SEM).

The usage of SEM helps the researcher to test the relationship between complex variable and to get the thorough overview about the model and SEM will test simultaneously. In this life, a man has a goal to be 
achieved in terms of life and kehidupannnya. Fulfillment of the goal is a provision in order to perform the role and function as human beings compared to other creatures. This goal is very important to be fulfilled so that if it fails, it will be difficult for a man to run its role and function. Then, based on that fact, the indicator for the life purpose variable refers to the goal to live meaningfully, financial goals, spiritual goals and goals to gain freedom.

A person who has the ability, skills and high knowledge does not necessarily generate high work performance. The achievement shown by a person in the organization is determined not only by his or her skills, knowledge, and abilities but is also determined by other factors such as motivation, intention from within a person to use all his/her abilities. According to Bahri (2002: 115), intrinsic motivation that the motives that become active or functioning does not require external stimulation, within each individual there is a driver to do something. Thus, the indicators of intrinsic motivation are achievement, recognition of others, responsibility and opportunities to move forward.

Job performance is the work of an employee during a certain period compared to various possibilities such as standard, target or criteria that has been determined in advance and mutually agreed. Handoko (2007: 135) revealed that Job achievement is a result of work achieved by the organization in evaluating or assessing its employees, thus the definition of it can be concluded as the work of a person based on the loads of responsibility given to him. Indicators of job achievement according to Anwar Prabu Mangkunegara (2009: 67) are quality, quantity, implementation of duties and responsibilities.

\section{Model of Measurement Test}

\section{Results}

The model of measurement test is part of the SEM model consists of a latent variable (construct) and several manifest variables (indicator) that describes the latent variable. Based on the calculation of Structural Equation Modeling (SEM) using the AMOS (Analysis of Moment Structure) version 22.0, all Loading Factors were significant at alpha $5 \%$, and this value is said as valid because the loading value is above 0.60 and the value of $\mathrm{p}$ value $<0,05$ (Ghozali, 2014: 138)

\subsection{Structural Equation Model}

\section{Analysis}

After testing the SEM assumptions and the data results obtained are eligible to be used, then the analysis can be continued with the suitability test model and the significance of causality test. The results of model conformance testing are presented in the following table.

Table 1. Model Conformance Testing

\begin{tabular}{|c|l|c|c|c|}
\hline No & Goodness of fit & Cut - of - value & Result & Remark \\
\hline 1 & Chi Square & Small Expectation & 45.144 & Fit \\
\hline 2 & Significance Prob & $\geq 0,05$ & 0,704 & Fit \\
\hline 3 & RMSEA & $\leq 0,08$ & 0,000 & Fit \\
\hline 4 & GFI & $\geq 0,90$ & 0,956 & Fit \\
\hline 5 & AGFI & $\geq 0,90$ & 0,932 & Fit \\
\hline 6 & CMIN/DF & $\leq 2,00$ & 51,00 & Fit \\
\hline 7 & TLI & $\geq 0,90$ & 1,010 & Fit \\
\hline 8 & CFI & $\geq 0,95$ & 1,000 & \\
\hline
\end{tabular}

Based on the calculation results obtained from Table 1, the results shows that the model has been appropriate, as shown on the parameter values which meet the criteria of model conformance test.

\subsection{Result}

The conceptual model shown in Figure 1 shows the life purpose has a significant influence with the positive direction of intrinsic motivation. This can be seen from the positive coefficient 0.309 with CR value of 2.932 and obtained probability significance (p) of 0.003 smaller than the level of significance $\alpha$ is set at 0.05 . Thus, the life purpose variable has a significant effect on intrinsic motivation. These results provide a support for the first hypothesis, the variable of life goals has a positive and significant effect on intrinsic motivation.

Second, the variable of life purpose has a significant influence with the positive direction toward the work performance. This can be seen from the positive coefficient 0.185 with CR value of 1.922 and obtained the probability significance (p) of 0.054 that is smaller than the significance level $\alpha$ is set at 0.05 . Thus the variable of life purpose significantly influences the job achievement. These results do not provide support for the second hypothesis, the variable of life goals has a positive and significant impact on work performance.

Third, intrinsic motivation has a significant effect on the positive direction on work performance. This can be seen from the positive signified coefficient of 0.212 with a CR value of 2.244 and obtained the 
probability significance (p) of 0.025 that is smaller than the level of significance $\alpha$ is set at 0.05 . Thus, intrinsic motivation variables significantly influence job achievement. These results provide support for the third hypothesis, intrinsic motivation variables have a positive and significant impact on job achievement.

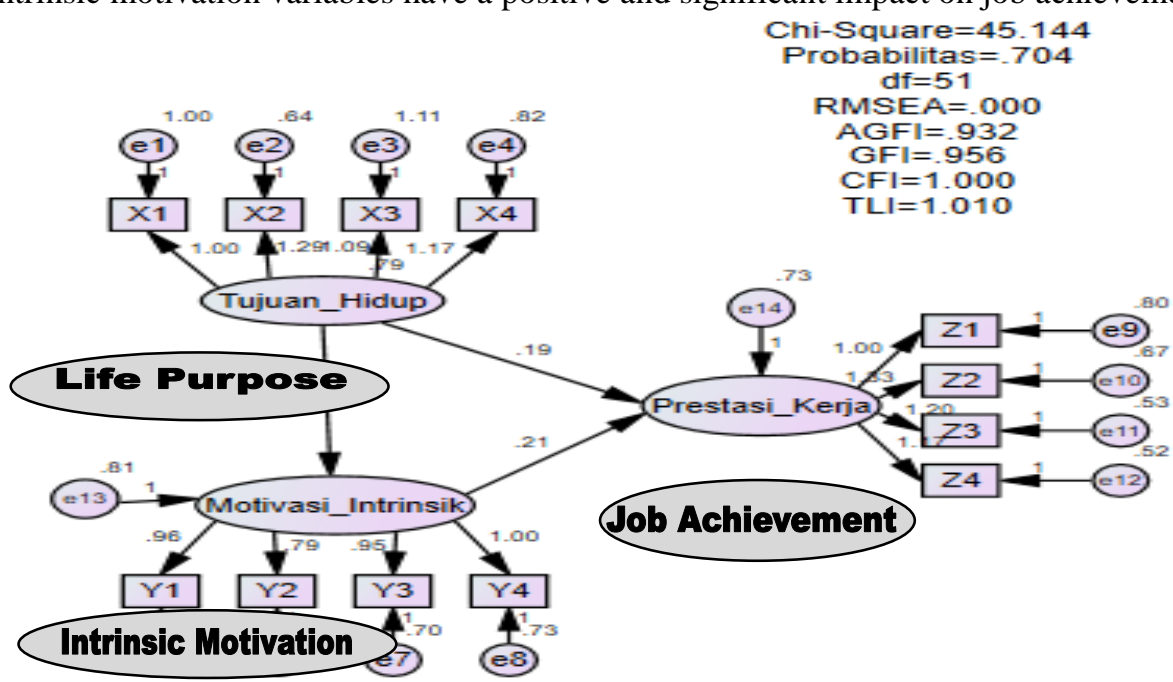

Source : Output Amos Ver 22.0

Figure 1.: Conceptual Model

\section{Discussion}

The main purpose of this study was to examine the relationship between the life purpose to intrinsic motivation and its impact on job achievement. The results of SEM show the following three findings. First, this study reinforces that life purpose have a significant effect on intrinsic motivation. These findings reinforced Edwin Locke's theory of Goal setting Theory which said that "the farther a person determines his life purpose, the stronger the motivation to live his life".

The second finding of the study reinforced the assertion that life purpose has a significant effect on performance. This research is reinforced by Victor Frankl's theory that everyone wants themselves to be a dignified and useful person for himself, his family, the working environment, the community and precious to God. The desire to live meaningfully is really the main motivation in humans. This desire is what encourages everyone to perform various activities such as work to make his life meaningful and valuable.

The third findings of this study reinforces the claim that intrinsic motivation has a significant effect on job achievement. The result of the analysis shows that intrinsic motivation has a significant influence on job achievement. This study is reinforced by the theory According to Herzberg quoted by Luthans (2011: 160) who said that intrinsic motivation is the motivation that encourages a person to excel that comes from within the individual, and known as motivational factors. This research is also supported by research Akbar (2013) in his research proves that intrinsic motivation has a positive effect on job achievement.

\section{Conclusion}

Based on the results of research that has been done on Paper Mill in East Java about the influence of life purpose on intrinsic motivation and its impact on job achievement can be drawn some conclusions are as follows :

a. The life purpose has a significant effect on the positive direction of intrinsic motivation. This can be seen from the positive coefficient 0.309 with CR value of 2.932 and obtained probability significance (p) of 0.003 smaller than the level of significance $\alpha$ is set at 0.05 . This shows that the variable of life goal has a significant effect on intrinsic motivation.

b. The life purpose has a significant effect on the positive direction of job achievement. This can be seen from the coefficient of positive marked 0.185 with CR value of 1.922 and obtained the probability significance (p) of 0.054 is smaller than the significance level $\alpha$ is set at 0.05 . This shows that the variable of life purpose significantly affects job achievement

c. Intrinsic motivation has a significant effect on the positive direction on job achievement. This can be seen from the positive signified coefficient of 0.212 with a CR value of 2.244 and obtained the probability significance (p) of 0.025 is smaller than the level of significance $\alpha$ is set at 0.05 . This shows that intrinsic motivation variables significantly influence job achievement. 


\section{Recomendation}

As this study attempts to examine the relationship between life purpose, intrinsic motivation and job achievement at Paper Mill in East Java, when conducting this research in the process of collecting data using questionnaires distributed to employees of Paper Mill as respondents, the results obtained are difficult to be controlled because it may not fit the actual situation.

Judging from the answers of each respondent shows there are some very extreme results. It is possible that respondents are not really serious in filling out the questionnaires provided by researchers, so the results may not fully reflect what respondents actually experienced when they were interviewed.

It needs further research on the variables that affect job achievement such as additional load due to work environment such as physical factors: lighting, temperature and physiological factors such as leadership style to performance. The next research related to the workforce should adjust to the spare time of the employees so that the data retrieval does not interfere the working process.

\section{Reference}

[1] Akbar, Nurtaneo, Febrian. 2013. Pengaruh Motivasi Intrinsik dan Motivasi Ekstrinsik Terhadap Kinerja Karyawan Pada PT Perkebunan Nusantara XII Surabaya: (online), (diakses 18 Maret 2017).

[2] Bahri, Syaiful. 1997. Strategi belajar mengajar. Rineka Cipta. Jakarta

[3] Bastaman, 2007. Meraih hidup bermakna, Paradigma. Jakarta

[4] Handoko, T Hani. 2014. Manajemen Personalia \& Sumberdaya Manusia. Edisi Kedua. Cetakan Ke-21. Yogyakarta: BPFEYOGYAKARTA

[5] Imam Ghozali, 2014, Konsep dan Alpikasi dengan AMOS 22.0, UNDIP, Semarang

[6] Mangkunegara, A.A. Anwar Prabu. 2013. Manajemen Sumber Daya Manusia Perusahaan. Bandung: Remaja Rosdakarya.

[7] Mondy, R Wayne. 2008. Manajemen Sumber Daya Manusia. Jilid 2. Edisi 10. Jakarta: Penerbit Erlangga.

[8] Bintoro, Julia Astriviani. 2013. Pengaruh Tujuan hidup Finansial dan Non Finansial terhadap Prestasi kerja. Skripsi Tidak Diterbitkan. Malang: Fakultas Ilmu Administrasi Universitas Brawijaya.

[9] Rivai, V dan Sagala, E J. 2011. Manajemen Sumber Daya Manusia untuk Perusahaan. Jilid 2. Cetakan Ke-4. Jakarta: Rajagrafindo Persada.

[10] Singgih santoso, 2014, Konsep Dasar dan Aplikasi SEM dengan AMOS 22, Gramedia, Jakarta.

[11] Sofyandi, Herman. 2013. Manajemen Sumber Daya Manusia. Edisi Pertama. Cetakan Ke-2. Yogyakarta: Graha Ilmu.

[12] Sugiyono. 2013. Metode Penelitian Pendidikan. Cetakan Ke-16. Bandung: Alfabeta.

[13] Sutrisno, Edy. 2014. Manajemen Sumber Daya Manusia. Edisi Pertama. Cetakan Ke-6. Jakarta: Kencana Prenada Media Group

Maya Ida Kesumawatie. "The Influence of Life Purpose to Instrinsic Motivation and Job Achievement among the Employees of Paper Mill Factory in East Java Province, Indonesia ." IOSR Journal of Business and Management (IOSR-JBM) 19.7 (2017): 10-14. 